\title{
Dental Health Estimation for Children Age Twelve and Fifteen
}

\author{
Bojana Davidović ${ }^{1}$, Mirjana Ivanović ${ }^{2}$, Svjetlana Janković ${ }^{1}$ \\ ${ }^{1}$ Department for Pediatric and Preventive Dentistry, Dentistry Program, School of Medicine, \\ University of East Sarajevo, Foča, Bosnia and Herzegovina; \\ ${ }^{2}$ Clinic for Pediatric and Preventive Dentistry, School of Dentistry, University of Belgrade, Belgrade, Serbia
}

\begin{abstract}
SUMMARY
Introduction The problem of chronic diseases such as caries is very complex because it appears very early in life, often during childhood. The number of involved people is growing as well as the number of affected teeth and surfaces that eventually lead to teeth loss. The aim of this study was to determine the dental status of adolescents age 12 and 15 in three municipalities in Bosnia, Foca, Cajnice and Kalinovik.

Material and methods The study included 506 school children both genders of six schools in three municipalities (Foca, Cajnice and Kalinovik). Teeth examination and criteria for diagnosis and coding were estimated based of criteria of the European Academy of Paediatric Dentistry (EAPD). To estimate dental health DMFT index [number of carious teeth (D), missing (M) and filled teeth (F)] and related indices (Person Caries Index, Teeth Caries Index, Average Caries Index and DMFT structure) were used.

Results Dental health status and caries prevalence were presented through the values of the Average Caries Index. The value of Average Caries Index for examined children was 6.17. Of all examined children $96.05 \%$ of them had at least one carious tooth. The average value of Teeth Caries Index was $23.04 \%$.

Conclusion Dental health of the children in the examined region was characterised by high values of untreated carious teeth as well as the other components of DMFT index. Therefore, preventive measures and primary dental care must be implemented better among school children.
\end{abstract}

Keywords: dental caries; epidemiology; health; children

\section{INTRODUCTION}

The fact that health has been subject of interest and interpretation of experts in various scientific disciplines for many years designates its universal value; however, it can be completely and satisfactorily discussed only from medical and biological point of view. Good oral health implies much more than healthy teeth and represents an integral part of general health becoming significant for good quality of life. As the most prevalent human disease, caries has a great health and socio-economic significance. Results of many early studies have indicated that oral health among the population has not been on the satisfactory level. For example, the number of carious teeth in twelve-year-old children in West Europe was higher than 5 and in fifteenyear-olds the number was often above 10 [1].

Studies that revealed first statistical analyses of caries prevalence have been published at the beginning of the $20^{\text {th }}$ century. First epidemiological studies using randomised sample have been conducted in the United States and England in the sixties of the previous century; later this practice has been carried out in other countries as well [1]. These studies have become frequent due to the need for perceiving important facts about the prevalence, characteristics and specific features of teeth diseases.
Currently, the prevalence of teeth diseases is decreasing in great number of European countries, as well as in North America. Reasons for huge decline in caries prevalence are numerous and complex, but most often explained by change of lifestyle and better life quality, continuing application of fluoride in different forms, improvement in oral hygiene and systematic school preventive programmes [2].

Caries prevalence in industrialized countries is the highest in the most vulnerable social groups such as ethnic minorities. In developing countries [3] a reverse trend has been noticed; children from urban areas have the highest caries prevalence. Although oral health in West European countries has been improved, some unexpected changes have been noticed. Thus the population migration has been identified as a new factor for increasing the caries prevalence in Switzerland [1]. On the other hand, data from Central Europe are not so encouraging, even though in some countries, such as Slovenia and Hungary [4], positive trend and oral health improvement have been noticed. The results of the study aimed to examine caries prevalence among school children in Poland for the period 1995-2000, as well as to evaluate renewed preventive programs in schools, [5] showed that the use of healthcare services mostly depends on whether the population lives in rural or urban areas. The average caries index in 12-year- 
olds was 4.2 in 1995; 4.0 in 1997 and 1999, 3.8 in 2000, indicating that renewal of school preventive programmes had made positive effect on oral health improvement of the children. In Poland, the children from urban areas have had better oral health in comparison to the children from rural areas, where carious teeth have dominated in DMFT structure.

Results of many studies have confirmed that caries is one of the most common diseases of children and adolescents. With the improvement of oral health people's comprehension of oral health has also been improved, as well as considerable increase in knowledge and positive attitude among children and parents [6]. On the other hand, new data analysis on caries prevalence among twelve-yearold children and adolescents age fifteen has shown that caries is still one of the greatest health and social problems in East and Central European countries [7].

The aim of this study was to determine caries prevalence and characteristics of DMFT index in children age twelve and fifteen in municipalities of Foca, Cajnice and Kalinovik in order to improve oral health prevention.

\section{MATERIAL AND METHODS}

Epidemiological study was based and designed according to the recommendations of the World Health Organization (WHO) for epidemiological surveys of national oral pathology [8]. In the first phase, survey charts, the sample, standards and indices were determined. By the epidemiological research plan, all children age twelve and fifteen from municipalities Foca, Cajnice and Kalinovik were included in the study. After obtaining the approval from the Ethical Committee of Medical Faculty Foca and school managers as well as signed informed consent from parents/guardians, the study started according to the predefined schedule. The survey was conducted in 2007.

Teeth examination and criteria for diagnosis and coding teeth health condition were estimated based on criteria of European Academy of Pediatric Dentistry (European Academy of Paediatric Dentistry - EAPD) [8]. A tooth was considered carious if the cavity was determined by visual inspection on the occlusal, proximal, buccal or oral surface. A tooth with temporary filling was classified carious as well. A tooth that had white spot present or coloured and rough surface with deep fissure was classified as healthy [8]. Dental status was registered according to Klein-Palmer's DMF system (D - decayed tooth, $\mathrm{M}$ - missing tooth, F - filled tooth) [9].

School children in Foca were examined in school dental office. Examination was performed using: dental mirror, probe and regular light in the workplace. Dental probe was used only to remove a considerable amount of plaque from a tooth surface. Examination of children from suburban schools that are part of one of the schools in Foca, as well as from schools in Kalinovik and Cajnice were performed in the classroom with best light using the same dental instruments. Third molars not present in mouth as well as deciduous teeth were excluded from evaluation.
There are two primary schools in the municipality of Foca - Veselin Maslesa, Foca (VMF) and Sveti Sava, Foca (SSF) - located in the centre of the town, but they have included its suburban schools - Veselin Maslesa, Brod (VMB) and Sveti Sava, Miljevina (SSM). Four specialists in preventive and pediatric dentistry have been covering oral and dental health of children from the territory of Foca. One school from Cajnice - Jovan Ducic, Cajnice (JDC), as well as one from Kalinovik - Ljutica Bogdan, Kalinovik (LJBK), were also included in the study. Since there were only few children at examined age in suburban schools that are part of these schools, they were not included in the survey.

\section{RESULTS}

In the epidemiological survey 506 school children were examined: 324 aged 12 years and 182 aged 15 years. Approximately the same number of boys (263; 51.97\%) and girls $(243 ; 48.03 \%)$ participated in the study. Data analysis showed that Person Caries Index (PCI) was high (96.05\%). PCI had the lowest value in the school VMF (93.84\%) and the highest value in the school JDC (100\%), but without statistical difference $(t=1.097 ; p>0.05)$. Other values by schools are shown in Table 1 .

According to this survey only $4 \%$ of children had all healthy teeth. The lowest DMFT value was 1 and found in $2.2 \%$ of the children, whereas the highest DMFT value was 21 found in $0.2 \%$ of the children. The most frequent value of DMFT was 4 and it was found in $16.4 \%$ of the children. Fifteen children attending schools in the town of the municipality of Foca had the highest number of healthy teeth, whereas no child from the school JDC had all healthy teeth.

In the group of boys, only $4.2 \%$ had all healthy teeth, in $17.1 \%$ DMFT value was 4 while in $0.4 \%$ of boys DMFT value was 21. Similar condition was found in girls. Among them $3.7 \%$ had all healthy teeth. The DMFT value 4 was found in $15.6 \%$ of girls. Found difference was not statistically significant $(\mathrm{t}=0.948 ; \mathrm{p}>0.05)$. Among 12 -year-old children, $3.7 \%$ had all healthy teeth. The most common DMFT value 4 was found in $19.4 \%$ of twelve-year-olds. In

Table 1. Distribution of Person Caries Index by schools Tabela 1. Distribucija karijes-indeksa osobe po školama

\begin{tabular}{|c|c|}
\hline $\begin{array}{c}\text { School } \\
\text { Škola }\end{array}$ & $\begin{array}{c}\text { Person Caries Index } \\
\text { Karijes-indeks osobe }\end{array}$ \\
\hline VMF & $93.84 \%$ \\
\hline VMB & $95.65 \%$ \\
\hline SSF & $96.52 \%$ \\
\hline SSM & $96.55 \%$ \\
\hline LJBK & $95.23 \%$ \\
\hline JDČ & $100 \%$ \\
\hline Total / Ukupno & $96.05 \%$ \\
\hline
\end{tabular}

VMF - Veselin Maslesa, Foca (city school); VMB - Veselin Maslesa, Brod (suburban school); SSF - Sveti Sava, Foca (city school); SSM - Sveti Sava, Miljevina (suburban school); LJBK - Ljutica Bogdan, Kalinovik (city school); JDČ - Jovan Ducic, Cajnice (city school)

VMF - Veselin Masleša, Foča (gradska škola); VMB - Veselin Masleša, Brod (vangradska škola); SSF - Sveti Sava, Foča (gradska škola); SSM - Sveti Sava, Miljevina (vangradska škola); LJBK - Ljutica Bogdan, Kalinovik (gradska škola); JDČ - Jovan Dučić, Čajniće (gradska škola) 
Table 2. Distribution of Teeth Caries Index by schools

Tabela 2. Distribucija karijes-indeksa zuba po školama

\begin{tabular}{|c|c|}
\hline $\begin{array}{c}\text { School } \\
\text { Škola }\end{array}$ & $\begin{array}{c}\text { Teeth Caries Index } \\
\text { Karijes-indeks zuba }\end{array}$ \\
\hline VMF & $21.17 \%$ \\
\hline VMB & $27.97 \%$ \\
\hline SSF & $22.7 \%$ \\
\hline SSM & $24.37 \%$ \\
\hline LJBK & $21.9 \%$ \\
\hline JDČ & $24.67 \%$ \\
\hline Total & $23.03 \%$ \\
\hline
\end{tabular}

Table 3. Distribution of Average Caries Index by schools Tabela 3. Distribucija proseka karijes-indeksa po školama

\begin{tabular}{|c|c|}
\hline $\begin{array}{c}\text { School } \\
\text { Škola }\end{array}$ & $\begin{array}{c}\text { Average Caries Index } \\
\text { Karijes-indeks prosek }\end{array}$ \\
\hline VMF & $5.74 \%$ \\
\hline VMB & $7.24 \%$ \\
\hline SSF & $6.19 \%$ \\
\hline SSM & $6.59 \%$ \\
\hline LJBK & $5.67 \%$ \\
\hline JDČ & $6.40 \%$ \\
\hline Total & $6.17 \%$ \\
\hline Ukupno & \\
\hline
\end{tabular}

the group of fifteen-year olds, $4.4 \%$ of them had healthy teeth, in $11.0 \%$ the value of DMFT was 4 , and in $0.5 \%$ the DMFT value was 21 . There was no significant difference in the terms of age of examinees $(t=0.383 ; \mathrm{p}>0.05)$.

The Teeth Caries Index (TCI) of all children included in the survey was $23.04 \%$. The highest TCI value was found in the school VMB (27.9\%), and the lowest in the school VMF (21.2\%). There was significant difference between these schools $(\mathrm{F}=1.732 ; \mathrm{p}<0.05)$. According to the intergroup analysis, TCI values were significantly lower in both urban schools in Foca than in the school VMB (Table 2). Data analysis of TCI values in terms of gender $(22.75 \%$ in boys and $23.35 \%$ in girls) using Student's t-test did not show significant difference $(t=0,459 ; \mathrm{p}>0.05)$. Comparison of TCI values between age groups (21.52\% in twelve-yearolds and $25.72 \%$ in fifteen-year-olds) confirmed highly statistically significant difference $(t=3.136 ; \mathrm{p}<0.01)$.

Average Caries Index (ACI) per examinee was 6.17. ACI values in all school were high (Table 3 ). The highest ACI value was recorded in the school VMB (7.24), while the lowest were obtained from the schools LJBK (5.67) and VMF (5.74). Analysis of variance did not show statistically significant difference in terms of ACI between schools $(\mathrm{F}=1.189 ; \mathrm{p}>0.05)$. There was no significant difference in ACI values between boys (6.01) and girls (6.35) $(t=0.948$; $\mathrm{p}>0.05)$. Comparing the ACI values of twelve-year-olds (5.64) and fifteen-year-olds (7.12), statistically significant difference was found $(\mathrm{t}=4.039 ; \mathrm{p}<0.01)$.

The DMFT analysis revealed the following results: out of 13,552 examined teeth, 3,125 of them were carious. Analysis of the structure of DMFT index showed that there were more treated teeth (extractions and fillings; $59.52 \%$ ) than non treated teeth i.e. carious teeth $(40.48 \%)$, whereas the number of extracted teeth was not negligible as well (Graph 1). Every seventh child had at least one extracted tooth. Taking into consideration observed

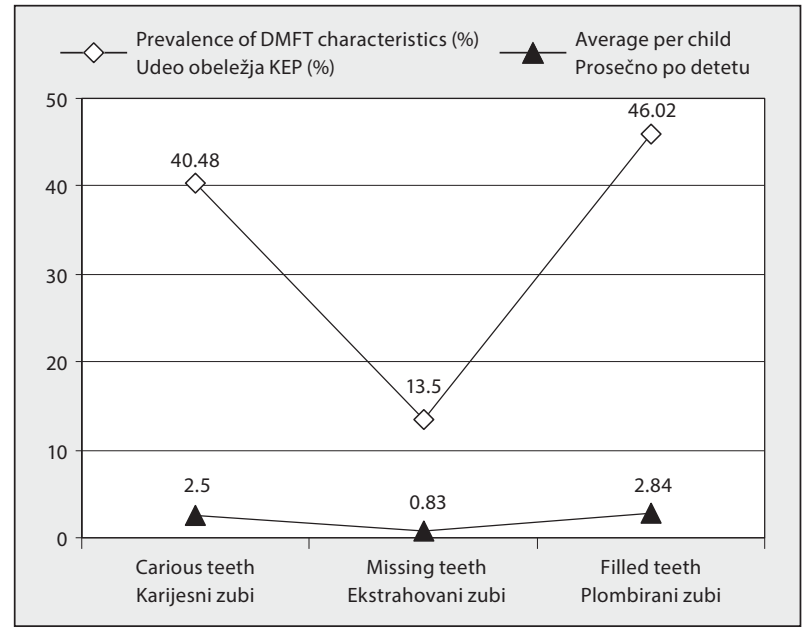

Graph 1. Interrelation of DMFT characteristics and their average values

Grafikon 1. Međusobni odnos obeležja indeksa KEP i njihove prosečne vrednosti

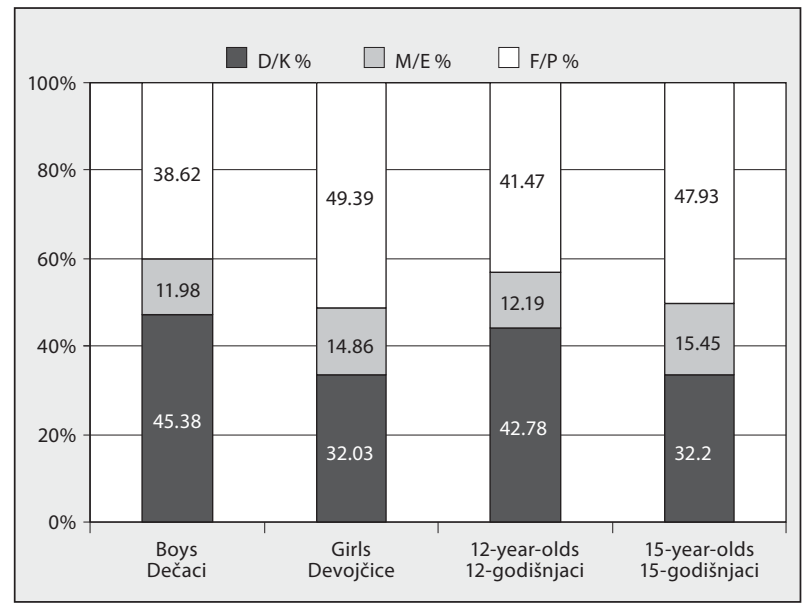

Graph 2. Distribution of individual DMFT values (\%) in relation to gender and age of respondents

Grafikon 2. Distribucija pojedinačnih vrednosti indeksa KEP (\%) u odnosu na pol i uzrast ispitanika

${ }^{*}$ statistically significant $(p<0.05)$; ** highly statistically significant $(p<0.01)$

${ }^{*}$ statistički značajno $(p<0,05)$; ${ }^{* *}$ visoko statistički značajno $(p<0,01)$

characteristics, gender and age, almost no difference was found in the DMFT structure (Graph 2). Presence of non treated caries was more common in boys (45.39\%) than in girls $(32.03 \%)$ where statistically significant difference was found $(t=2.794 ; \mathrm{p}<0.01)$, although the difference was not found between groups according to age $(t=0.931$; $\mathrm{p}>0.05)$. There was statistically significant difference in the terms of extracted teeth between genders $(t=2.171$; $\mathrm{p}<0.05$ ) (girls had more extracted teeth) as well as between age groups $(t=2.251 ; \mathrm{p}<0.05)$ (fifteen-year-olds had more extracted teeth). Girls also had higher number of fillings $(49.39 \%)$ than boys $(38.62 \%)$, the difference was statistically significant $(\mathrm{t}=2.902 ; \mathrm{p}<0.01)$. The difference was also significant between age groups $(t=5.320 ; p<0.01)$ since fifteen-year olds had more fillings (47.93\%). Generally, girls have visited dentist more often, therefore they had considerably more treated teeth than boys. Twelve year old children have visited dentist less frequently, therefore they had considerably higher number of carious teeth as compared to fifteen-year-olds. 


\section{DISCUSSION}

Epidemiological surveys on dental health condition have shown a huge diversity of caries occurrence. In contrast to West European countries, in the countries of East and Southeast Europe the problem of caries is still present as well as consequent complications. The results of the current study indicated that oral health of the examined children was not satisfactory. Average Caries Index (ACI) value of all examinees was 6.17, whereas Person Caries Index (PCI) was $96.05 \%$. According to the study, ACI value in twelveyear-olds was 5.64 while in fifteen year-olds it was 7.12.

First data from this region was recorded in 1986 [10]. Vrbic et al. [10] found high values of ACI (6.1) in twelveyear-olds and 9.6 in fifteen-year-olds. Only a few surveys about the caries prevalence have been conducted in Bosnia and Herzegovina in the last decades. According to the survey performed in Sarajevo in 1999 [11], caries prevalence in children age 12 to 15 was $96.98 \%$ or averagely 7.18 of diseased teeth per person. Similar results were obtained in the current study. During 1997, Ivankovic et al. [12] found carious teeth in $94 \%$ of twelve-year-olds in the West Herzegovina Canton, Herzeg-Mostar Canton and Posava Canton, whereas ACI was 6.2. Obradovic and Dotlic [13] analysed dental health in twelve-year-olds from Banja Luka and reported higher values of ACI value in children from rural areas (6.74) than in children from urban areas (4.89). The study that encompassed the largest area of Bosnia and Herzegovina was conducted in 2008 [14]. On the sample of 560 twelve-year-olds, ACI value was determined as 4.16. In all aforementioned surveys the value of component $\mathrm{D}$ (decayed) was the highest, following by component $\mathrm{F}$ (fillings) and component $\mathrm{E}$ (missing).

Rajic et al. [15] compared dental health of twelveyear-olds in Croatia during three decades. The decrease in caries prevalence from 7.0 in 1968 to 3.5 in 1999 was attributed to the local application of fluorides in the forms of Na-fluorides and amid-fluorides through the preschool preventive programme, as well as preventive prophylactic application during pregnancy. After examination of 227 children age 11 to 14 from the areas of Petrinje and Topusko [16], high values of ACI (6.67) were found. The values were higher in children from rural and subrural areas [16]. Recent survey conducted on the territory of Montenegro [17] revealed lower ACI values in twelveyear-olds as compared to the current study. ACI value in twelve-year-olds was 3.43, whereas the percentage of children with carious permanent teeth was $88.35 \%$. On the territory of Serbia, Kostadinovic et al. [18] found that, thankful to well developed school dental care, children of age 13 in the region of Nis had lower values of ACI (3.60) as compared to their peers from Surdulica (9.18). The latest data was obtained from the study conducted in 2009 by the Clinic of Pediatric and Preventive Dentistry of the School of Dentistry in Belgrade in order to design the preventive programme in the Republic of Serbia [19, 20]. Results showed that in twelve-year-old children ACI value was 2.8 , while in fifteen-year-olds it was 5.6. Wellorganized preventive programmes, regular teeth brushing using pastes that contain fluorides and other means for oral hygiene as well as the prophylactic fissure sealing in Slovenia [4] led to decrease in caries prevalence and ACI from 5.1 (1987) to 1.8 (1998) in twelve-year-olds and from 10.2 to 4.3 in fifteen-year-olds. National survey conducted in Italy in 2004/2005 on children age 12 showed ACI value of 1.09 [21], with statistically significant difference between genders (in girls 1.20, in boys 0.99). For the period from 1985 to 1996, improved oral hygiene habits, fluoride application, most commonly in the forms of pills and gels as well as the use of toothpastes rich in fluoride resulted in decline of caries prevalence in twelve-year-olds from 5 to 3.8 in Hungary [22]. Preventive programmes and teacher involvement in spreading information about the importance of oral health in Poland within five years period (1995-2000) resulted in decreased ACI values from 4.2 to 3.8 [5]. Until the year 2020, as expected by WHO, ACI value for twelve-year-olds should reach 1.5 [23]. However, this was already achieved in Scandinavian countries [24]. In Denmark ACI value was 0.8 , in Sweden 1.0, in Finland 1.2, and in Norway 1.6, while in twelveyear-olds from Portugal it was 1.5 [25].

Family plays an important role in acquiring positive attitudes on general health, as well as oral health. School has also a great impact on developing normal personality by its pedagogical-educational work. However, advices and prophylactic-therapeutic interventions provided by medical doctors are highly valuable for maintaining and improving health. A pediatric dentist is a person who, thanks to the regular check ups, has the opportunity to notice changes in oral cavity and timely apply the corresponding treatment. According to criteria for caries prevalence in twelve-year-old children, as stated by WHO [23], the value found in this study was high $(\mathrm{ACI}=5.64)$.

Caries is still responsible for the majority of health problems in industrialized countries, as well as developing countries due to increased sugar consumption, inadequate fluoride use and limited access to oral healthcare services. Therefore, it is necessary to correct the habits regarding consumed food as well as to improve oral hygiene and fluoride application whether by adding fluoride to drinking water, milk, salt, toothpastes or their combination.

Marthaler and Petersen [26] and Meyer-Luecker et al. $[27,28]$ pointed out to the advantage and practical aspects of adding fluoride to salt in order to decrease caries prevalence, reporting Jamaica and Switzerland as positive examples. The ACI in twelve-year-olds in Switzerland (the Canton of Zurich) [26] has decreased from 8.2 to 1.1 , whereas in some regions of Jamaica $[27,28] \mathrm{ACI}$ in twelve-year-olds was 2.2 (1999), 2.5 (2006), and 3.8 in fifteen-year-olds. The importance of fluoridised drinking water on lowering caries prevalence has been pointed out by Saliba et al [29]. Pontigo-Loyola et al. [30] reported the success of various fluoride applications in decreasing caries prevalence. However, according to the contemporary literature, a priority should be given to the local fluoride application.

The current study showed that ACI value was high in 12 and 15 years old children in the examined regions. They corresponded to the ACI values from the countries of North and West Europe reported couple of decades ago. It 
can be attributed to the period of socioeconomic instability and existential problems which has left consequences on children living in these regions.

\section{CONCLUSION}

Dental caries has been one of the most common oral diseases in this region. As dental health of children from the examined regions was considered inadequate, greater attention should be paid to preventive and prophylactic measures in order to maintain and improve oral health of the population. To improve oral health of children, beside the role of a dentist, the help of regulations legislated and applied by the state is also required.

\section{REFERENCES}

1. Marthaler TM. Changes in dental caries 1953-2003. Caries Res. 2004; 38:173-81.

2. Bratthall D, Petersen PE, Stjernswärd JR, Brown LJ. Oral and craniofacial diseases and disorders. In: Jamison DT, Breman JG, Measham AR, Alleyne G, Claeson M, Evans DB, Jha P, Mills A, Musgrove P, editors. Disease Control Priorities in Devoloping Countries. 2nd ed. Washington, DC: The International Bank for Reconstruction and Development/The World Bank; 2006. p.723-737.

3. Rugg-Gunn AJ. Dental caries. In: Welbury RR, editor. Paediatric Dentstry. Oxford, New York, Tokyo: Oxford University Press; 1997. p.95-113.

4. Vrbič V. Reasons for caries decline in Slovenia. Community Dent Oral Epidemiol. 2000; 28:126-32.

5. Wierzbicka M, Petersen PE, Szatko F, Dybizbanska E, Kalo I. Changing oral health status and oral health behaviour of school children in Poland. Community Dent Health. 2002; 19:243-50.

6. Vigild M, Petersen PE, Hadi R. Oral health behaviour of 12-year-old children in Kuwait. Int J Paediatr Dent. 1999; 9:23-29.

7. Petersen PE, Torres AM. Preventive oral health care and health promotion provided for children and adolescents by the Municipal Dental Health Service in Denmark. Int J Paediatr Dent. 1999; 9:81-91.

8. World Health Organization. Oral Health Surveys - Basic Methods. 4th ed. Geneva: WHO; 1997.

9. Vulović MD, Beloica D, Gajić M, Stevanović R, Ivanović MD, Carević MR, et al. Preventivna stomatologija. Beograd: Naučna knjiga; 2002.

10. Vrbic V, Vulovic M, Rajic Z, Topic B, Tatic E, Malic M, et al. Oral health in SFR Yugoslavia in 1986. Community Dent Oral Epidemiol. 1987; 16:286-8.

11. Kobašlija S, Maglajić N, Huseinbegović-Čengić A, Tahmiščija $H$. Prevalencija karijesa u djece u Sarajevu. Acta Stomatol Croat. 2000; 34:83-5.

12. Ivanković A, Lukić IK, Ivanković Z, Radić A, Vukić I, Šimić A. Dental caries in postwar Bosnia and Herzegovina. Community Dent Oral Epidemiol. 2003; 31:100-4.
13. Obradović M, Dolić O. Prevalencija karijesa i faktori rizika za njegov nastanak u urbanoj i ruralnoj sredini. Stomatološki glasnik Srbije. 2008; 55:34-42

14. Muratbegović A, Marković N, Kobašlija S, Zukanović A. Indeksi oralnog zdravlja i hipomineralizacija kutnjaka i sjekutića kod bosanske djece u dobi od 12 godina. Acta Stomatol Croat. 2008; 42:155-63.

15. Rajić Z, Radionović D, Rajić-Meštrović S. Trends in dental caries in 12-year old children in Croatia. Coll Antropol. 2000; 24:21-4.

16. Jurić H, Klarić T, Lulić-Dukić O. Pojavnost karijesa u djece s obzirom na oralno-higijenske navike i prijašnje karijes iskustvo. Acta Stomatol Croat. 2003; 37:340-1.

17. Đuričković M, Ivanović M. Stanje oralnog zdravlja kod dece uzrasta od 12 godina u Crnoj Gori. Vojnosanit Pregl. 2011; 68:550-5.

18. Kostadinović Lj, Aleksić B, Igić M, Šurdilović D, Tričković-Janjić O. Medicinski, socijalni i ekonomski značaj postojanja školske stomatološke nege. Acta stomatologica Naissi. 2011; 27:1043-58.

19. Ivanović M, Carević M, Marković D, Vulićević Z, Stevanović R, Petrović V, et al. Protokoli u stomatologiji. Beograd: Stomatološki fakultet; 2009.

20. Ivanović M, Carević M, Marković D. Program preventivne stomatološke zdravstvene zaštite dece i omladine. Zbornik referata i radova XXVI simpozijuma zdravstvenog vaspitanja u stomatologiji, Kragujevac. Stomatološki glasnik Srbije. 2010; 36-44.

21. Campus G, Solinas G, Cagetti MG, Senna A, Minelli L, Majori S, et al. National pathfinder survey of 12-year-old children's oral health in Italy. Caries Res. 2007; 41:512-7.

22. Szöke J, Petersen PE. Evidence for dental caries decline among children in an East European country (Hungary). Community Dent Oral Epidemiol. 2000; 28:155-60.

23. Hobdell M, Petersen PE, Clarkson J, Johnson N. Global goals for oral health 2020. Int Dent I. 2003; 53:285-8.

24. Johansson V, Söderfeldt B, Axtelius B. Oral B's Nordic Report on Oral Health. Caries Prevalence Among Children, Adolescents and Adults, and Periodontal Conditions among Adults in Denmark, Finland, Norway and Sweden. Malmö: Malmö University Faculty of Odontology; 2007.

25. De Almeida CM, Petersen PE, Jesus André S, Toscano A. Changing oral health status of 6 - and 12 -year-old school children in Portugal. Community Dental Health. 2003; 20:211-6.

26. Marthaler TM, Petersen PE. Salt fluoridation - an alternative in automatic prevention of dental caries. Int Dent J. 2005; 55:351-8.

27. Meyer-Lueckel H, Satzinger T, Kielbassa AM. Caries prevalence among 6- to 16-year-old students in Jamaica 12 years after the introduction of salt fluoridation. Caries Res. 2002; 36:170-3.

28. Meyer-Lueckel H, Bitter K, Hopfenmuller W, Paris S. Reexamination of caries and fluorosis experience of children in an area of Jamaica with relatively high fluorosis prevalence. Caries Res. 2009; 43:250-3.

29. Saliba NA, Moimaz SAS, Casotti CA, Pagliari AV. Dental caries of lifetime residents in Baixo Guandu, Brazil, fluoridated since 1953 a brief communication. J Publ Health Dent. 2008; 68:119-21.

30. Pontigo-Loyola AP, Medina-Solis CE, Borges-Yañez SA, Patiño-Marín $\mathrm{N}$, Islas-Márquez A, Maupome G. Prevalence and severity of dental caries in adolescents aged 12 and 15 living in communities with various fluoride concentrations. J Publ Health Dent. 2007; 67:8-13. 


\title{
Procena stanja zdravlja zuba dece uzrasta od 12 i 15 godina
}

\author{
Bojana Davidović1, Mirjana Ivanović2 ${ }^{2}$ Svjetlana Janković1 \\ ${ }^{1}$ Katedra za dječiju i preventivnu stomatologiju, Studijski program Stomatologija, Medicinski fakultet, \\ Univerzitet u Istočnom Sarajevu, Foča, Bosna i Hercegovina; \\ ${ }^{2}$ Klinika za dečju i preventivnu stomatologiju, Stomatološki fakultet, Univerzitet u Beogradu, Beograd, Srbija
}

\begin{abstract}
KRATAK SADRŽAJ
Uvod Problem hroničnih oboljenja, kao što je karijes, utoliko je složeniji jer se javlja relativno rano, još u dečjem uzrastu. Stalno obolevaju nove osobe, karijes zahvata nove zube, nove površine zuba i izaziva komplikacije koje na kraju dovode do gubitka zuba. Cilj ovog rada bio je da se utvrdi stanje zdravlja zuba dece uzrasta od 12 i 15 godina koji žive na teritoriji opština Foča, Čajniče i Kalinovik i analizira dobijeno stanje prema vrsti obeležja.

Materijal i metode rada U istraživanje je uključeno 506 učenika oba pola iz šest osnovnih škola s područja opština Foča, Čajniče i Kalinovik. Pregled zuba je obavljen, kriterijumi za dijagnozu postavljeni, a stanje zdravlja zuba procenjeni na osnovu kriterijuma Evropske akademije za dečju stomatologiju (EAPD). Kao parametri procene korišćeni su indeksi prosečnog broja karijesnih (K), ekstrahovanih (E) i plombiranih (P) zuba i njima srodni indeksi (Klo, Klz, Klp, struktura KEP).

Rezultati Stanje zdravlja zuba i prevalencije karijesa predstavljeni su kroz vrednosti prosečnog karijes-indeksa. Prosečna vrednost karijes-indeksa kod ispitanih učenika bila je 6,17. Karijes je dijagnostikovan kod 96,05\% pregledane dece. Srednja vrednost karijesindeksa bila je $23,04 \%$.

Zaključak Stanje zdravlja zuba ispitivane dece tri regiona odlikuju visoke vrednosti nesaniranog karijesa, ali i svih drugih obeležja KEP, što navodi na zaključak da se mere prevencije moraju efikasnije primenjivati, a primarna stomatološka zaštita bolje organizovati.
\end{abstract}

Ključne reči: karijes; epidemiologija; zdravlje; deca

\section{UVOD}

Činjenica da je zdravlje bilo i ostalo predmet interesovanja i tumačenja stručnjaka brojnih naučnih disciplina upućuje na zaključak da je ono univerzalne vrednosti, ali i na to da se celovito i na zadovoljavajući način može razmotriti samo s medicinsko-biološkog stanovišta. Dobro oralno zdravlje podrazumeva mnogo više od zdravih zuba i integralni je deo opšteg zdravlja, te kao takvo od primarnog značaja za kvalitetan život ljudi. Kao najčešće oboljenje čoveka, karijes ima veliki zdravstveni i socioekonomski značaj. Rezultati mnogih istraživanja pokazuju da oralno zdravlje stanovništva nije na zavidnom nivou. Primera radi, u Zapadnoj Evropi deca uzrasta od 12 godina imala su više od pet obolelih zuba, a petnaestogodišnjaci često i više od deset [1].

Početkom 20. veka objavljena su istraživanja s prvim statističkim analizama o prevalenciji karijesa. Šezdesetih godina urađene su prve epidemiološke studije u kojima je korišćen randomizirani uzorak, i to u Sjedinjenim Američkim Državama i Engleskoj, da bi se kasnije takva praksa ustalila i u drugim zemljama [1]. Istraživanja ovoga tipa postala su sve češća zbog potrebe za sagledavanjem važnih činilaca o rasprostranjenosti, osobinama i specifičnostima oboljenja zuba. Svedoci smo da se u velikom broju zemalja Evrope i u Americi primećuje trend smanjenja učestalosti oboljenja tvrdih zubnih struktura. Razlozi za veliko smanjenje rasprostranjenosti karijesa su brojni i složeni, ali se najčešće objašnjavaju promenom načina i kvaliteta života, kontinuiranom primenom fluorida u različitim oblicima, poboljšanjem higijene usta i zuba i sistematskim školskim programima prevencije [2].

$\mathrm{U}$ industrijski razvijenim zemljama učestalost karijesa je najveća kod najugroženijih društvenih grupa, i to češće kod etničkih manjina. U zemljama u razvoju [3] primećen je obrnuti trend: kod dece iz gradskih sredina veći je stepen učestalosti karijesa. Iako je u zemljama Zapadne Evrope došlo do poboljšanja oralnog zdravlja, ipak se uočavaju neke neočekivane promene. Tako je migracija stanovništva prepoznata kao novi faktor u povećanju celokupne prevalencije karijesa u Švajcarskoj [1]. S druge strane, podaci iz Centralne Evrope nisu toliko ohrabrujući, iako su u nekim zemljama zabeleženi pozitivan trend i poboljšanje oralnog zdravlja, kao npr. u Sloveniji i Mađarskoj [4]. Rezultati studije čiji je cilj bio da se ispitaju promene u rasprostranjenosti karijesa među decom školskog uzrasta u Poljskoj tokom perioda 1995-2000. godine, s posebnim ciljem procene obnovljenog programa prevencije u školama [5], ukazali su na to da korišćenje zdravstvenih službi umnogome zavisi od toga da li stanovništvo živi u seoskoj ili gradskoj sredini. Prosečna vrednost karijes-indeksa kod dvanaestogodišnjaka bila je $4,2 \mathrm{u}$ 1995, 4,0 u 1997. i 1999. i 3,8 u 2000. godini, što je pokazalo da je obnavljanje školskog programa prevencije dalo pozitivne rezultate na oralno zdravlje dece. U Poljskoj je bolje oralno zdravlje ustanovljeno kod dece koja su živela u gradu, u poređenju sa decom koja su živela na selu, kod kojih je i dalje u strukturi KEP dominirao karijes.

Rezultati ovih epidemioloških studija potvrđuju da je karijes jedno od najčešćih oboljenja dece i adolescenata. Uporedo s poboljšanjem oralnog zdravlja stanovništva zabeležena su sve češća pozitivna shvatanja ljudi o važnosti zdravlja usta i zuba, kao i značajno povećanje znanja i pozitivnih stavova u vezi s oralnim zdravljem među decom i roditeljima [6]. S druge strane, analizom novijih publikacija o rasprostranjenosti karijesa kod dece uzrasta od 12 godina i adolescenata uzrasta od 15 godina zapaženo je da je u zemljama istočne i centralne Evrope karijes i dalje veliki zdravstveni i društveni problem [7].

Cilj ovog rada bio je da se utvrdi rasprostranjenost karijesa i struktura KEP kod dvanaestogodišnjaka i petnaestogodišnjaka koji žive na području opština Foča, Čajniče i Kalinovik, kako bi se doprinelo boljoj prevenciji oboljenja usta i zuba. 


\section{MATERIJAL I METODE RADA}

Epidemiološko istraživanje je zasnovano i dizajnirano prema preporukama Svetske zdravstvene organizacije (SZO) za epidemiološka ispitivanja nacionalne oralne patologije [8]. U prvoj fazi formirani su studijski karton i uzorak i određene mere, standardi i indeksi koji će se primenjivati. Epidemiološkim istraživanjem predviđeno je da $u$ istraživanju učestvuju sva deca uzrasta od 12 i 15 godina s teritorije opština Foča, Čajniče i Kalinovik. Nakon odobrenja Etičkog komiteta Medicinskog fakulteta u Foči, dobijene saglasnosti direktora škola i pisane saglasnosti roditelja, odnosno staratelja dece, istraživanje je počelo prema unapred dogovorenom redosledu. Studija je urađena tokom 2007. godine.

Pregled zuba je obavljen, kriterijumi za dijagnozu postavljeni, a stanje zdravlja zuba procenjeni na osnovu kriterijuma Evropske akademije za dečju stomatologiju (European Academy of Paediatric Dentistry - EAPD) [8]. Vizuelnom inspekcijom procenjivano je da li postoji već formiran kavitet na okluzalnim, aproksimalnim, bukalnim i oralnim stranama zuba. Zub s privremenim ispunom takođe je kategorisan kao zub zahvaćen karijesom. Ukoliko je postojala dilema u vezi s postojanjem bele mrlje, obojene ili hrapave površine, odnosno duboke fisure, ovi zubi su kategorisani kao zdravi zubi [8]. Stanje zuba je utvrđeno na osnovu vrednosti indeksa KEP (K - karijes; E ekstrahovan zub; P - plombiran zub) [9].

Pregledi dece u gradskim školama Foče obavljeni su u školskoj stomatološkoj ambulanti. Za pregled su korišćeni stomatološko ogledalo, stomatološka sonda i uobičajena osvetljenja radnog mesta. Stomatološka sonda je jedino bila upotrebljena ukoliko je sa zuba trebalo ukloniti veću količinu naslaga. Pregledi dece u prigradskim školama, koje pripadaju jednoj od gradskih škola (Foča), kao i u školama Kalinovika i Čajniča, obavljeni su u najsvetlijoj učionici uz korištenje istih stomatoloških instrumenata. Treći molari koji još nisu nikli i zubi mlečne denticije isključeni su iz evaluacije.

U opštini Foča postoje dve osnovne škole - „Veselin Masleša”, Foča (VMF) i „Sveti Sava”, Foča (SSF) - koje se nalaze u centru grada, kao i dve područne škole u vangradskom naselju - „Veselin Masleša”, Brod (VMB) i „Sveti Sava”, Miljevina (SSM). Problemima zdravlja usta i zuba dece s teritorije Foče zaduženo je četvoro specijalista preventivne i dečije stomatologije. U ovo istraživanje uključene su po jedna gradska osnovna škola iz opština Čajniče i Kalinovik - „Jovan Dučić”, Čajniče (JDČ) i „Ljutica Bogdan”, Kalinovik (LJBK). Vangradske škole koje pripadaju ovim školama imaju zanemarljivo mali broj dece ispitivanog uzrasta, te nisu uključena u istraživanje.

\section{REZULTATI}

Istraživanjem je obuhvaćeno 506 dece: 324 uzrasta od 12 godina i 182 uzrasta od 15 godina. U istraživanju je učestvovao približno isti broj dečaka $(263 ; 51,97 \%)$ i devojčica $(243 ; 48,03 \%)$. Analizom podataka dobijenih ispitivanjem utvrđena je veoma visoka vrednost karijes-indeksa (96,05\%). Posmatrano po školama, vrednost ovog indeksa bila je najmanja u VMF $(93,84 \%)$, a najveća u JDČ (100\%), ali ova razlika nije bila statistički značajna $(\mathrm{t}=1,097 ; \mathrm{p}>0,05)$. Ostale vrednosti karijes-indeksa po školama date su u tabeli 1 .
Sve zdrave zube imalo je samo $4 \%$ dece. Najniža vrednost indeksa KEP bila je 1, a zabeležena je kod 2,2\% dece, dok je najviša vrednost od 21 utvrđena kod $0,2 \%$ dece. Najčešća vrednost indeksa KEP bila je 4, a zabeležena je kod 16,4\% učenika. Kod 15 dece koja pohađaju neku od škola u gradu opštine Foča ustanovljen je najveći broj zdravih zuba, u odnosu na decu iz škole JDČ, u kojoj nijedno dete nije imalo sve zdrave zube.

U grupi dečaka samo je 4,2\% bilo bez obeležja KEP, kod 17,1\% vrednost indeksa KEP bila je 4, a kod 0,4\% dečaka 21. Slično stanje uočeno je i kod devojčica. Među njima 3,7\% je imalo sve zdrave zube. Kod 15,6\% devojčica vrednost indeksa KEP bila je 4. Uočena razlika nije bila statistički značajna $(t=0,948 ; \mathrm{p}>0,05)$. Među dvanaestogodišnjacima 3,7\% dece imalo je sve zdrave zube. Najčešća vrednost indeksa KEP (4) utvrđena je kod 19,4\% ovih ispitanika. U grupi petnaestogodišnjaka kod 4,4\% ustanovljeni su svi zdravi zubi, kod 11,0\% vrednost indeksa KEP bila je 4, a kod 0,5\% učenika 21. Razlika između ove dve uzrasne grupe ispitanika nije bila statistički značajna $(\mathrm{t}=0,383 ; \mathrm{p}>0,05)$.

Procenat obolelih zuba (karijes-indeks zuba - KIz) za svu decu uključenu u ovo ispitivanje bio je 23,04\%. Najveća vrednost ovog indeksa zabeležena je u školi VMB $(27,9 \%)$, a najmanja u školi VMF (21,2\%). Jednofaktorskom analizom varijanse dobijena je statistički značajna razlika između posmatranih škola $(\mathrm{F}=1,732 ; \mathrm{p}<0,05)$. Analizom međugrupnih razlika obe gradske škole u Foči utvrđene su manje vrednosti KIz u odnosu na školu VMB (Tabela 2). Analizirajući podatke vrednosti KIz prema polu (22,75\% kod dečaka i $23,35 \%$ kod devojčica) Studentovim t-testom, nije uočena statistički značajna razlika $(\mathrm{t}=0,459 ; \mathrm{p}>0,05)$. Upoređujući vrednosti KIz između uzrasnih grupa $(21,52 \%$ kod dvanaestogodišnjaka i $25,72 \%$ kod petnaestogodišnjaka), potvrđena je visoko statistički značajna razli$\mathrm{ka}(\mathrm{t}=3,136 ; \mathrm{p}<0,01)$.

Prosečan karijes-indeks (KIp) po ispitaniku (odnosno KEP indeks) bio je 6,17. Vrednosti KIp prikazane po školama bile su visoke (Tabela 3). Najveća vrednost KIp zabeležena je u školi $\operatorname{VMB}(7,24)$, a najmanja u školama LJBK $(5,67)$ i VMF $(5,74)$. Jednofaktorskom analizom varijanse nije utvrđena statistički značajna razlika u KIp između škola $(F=1,189 ; \mathrm{p}>0,05)$. Studentovim t-testom analizirana je razlika u vrednostima KIp između dečaka $(6,01)$ i devojčica $(6,35)$, ali ni ovde nije bilo statistički značajne razlike $(t=0,948 ; \mathrm{p}>0,05)$. Upoređujući vrednosti KIp između dvanaestogodišnjaka $(5,64)$ i petnaestogodišnjaka $(7,12)$, dobijena je statistički značajna razlika $(t=4,039 ; \mathrm{p}<0,01)$.

Kada je u pitanju pojedinačna analiza indeksa KEP, od ukupno 13.522 pregledana zuba, kod 3.125 zuba ustanovljeno je neko od obeležja karijesa. Posmatrajući odnos između pojedinih obeležja indeksa KEP (K, E, P), primećuje se da je bilo više lečenih zuba (ekstrakcije i plombe; 59,52\%), nego nelečenih. Nesaniranih karijesnih lezija bilo je 40,48\%, ali nije zanemarljiv bio ni broj ekstrahovanih zuba (Grafikon 1). Svako sedmo dete imalo je po jedan izvađen zub. Analizirajući strukturu indeksa KEP procentualno, uzimajući u obzir pol i uzrast ispitanika, uočena je neznatna razlika (Grafikon 2). Nelečeni karijes je u većem procentu zabeležen kod dečaka $(45,39 \%)$ u odnosu na devojčice $(32,03 \%)$, a razlika je bila visoko statistički značajna $(\mathrm{t}=2,794 ; \mathrm{p}<0,01)$, dok između uzrasnih grupa razlika nije uočena $(t=0,931 ; p>0,05)$. Statistički značajna razlika postojala je u odnosu na broj ekstrahovanih zuba između dečaka i devojčica $(t=2,171 ; p<0,05)$, gde su učenice imale veći broj izvađenih zuba. Razlika je uočena i između uzrasnih grupa $(\mathrm{t}=2,251$; 
$\mathrm{p}<0,05)$, gde je veći broj izvađenih zuba ustanovljen kod petnaestogodišnjaka. Takođe je kod devojčica utvrđen veći broj ispuna (49,39\%) nego kod dečaka (38,62\%), a razlika je bila visoko statistički značajna $(\mathrm{t}=2,902 ; \mathrm{p}<0,01)$. Razlika je bila statistički značajna i između uzrasnih grupa $(t=5,320 ; p<0,01)$, budući da je kod petnaestogodišnjaka zabeležen veći procenat ispuna (47,93\%). Uopšteno gledano, devojčice su češće posećivale stomatologa, pa je samim tim i broj lečenih zuba kod njih bio značajno veći nego kod dečaka. Učenici uzrasta od 12 godina nešto ređe su odlazili kod zubnog lekara i stoga su imali znatno veći broj zuba zahvaćenih karijesom u poređenju sa starijim učenicima.

\section{DISKUSIJA}

Epidemiološka istraživanja stanja zdravlja zuba u mnogim zemljama ukazuju na velike razlike u pojavi karijesa. U poređenju sa zemljama zapadne Evrope, u Istočnoj i Jugoistočnoj Evropi problem karijesa i dalje postoji, a značajne su i komplikacije do kojih on dovodi. Rezultati naše studije ukazuju na loše stanje zdravlja zuba dece ovog regiona. Vrednosti prosečnog karijes-indeksa (KIp) za sve pregledane ispitanike bio je 6,17, a karijes-indeks osobe 96,05\%. KIp kod dvanaestogodišnjaka bio je 5,64, a kod dece uzrasta od 15 godina 7,12.

Prvi podaci o stanju oralnog zdravlja stanovnika ovog područja zabeleženi su još 1986. godine [10]. Vrbič i saradnici [10] ukazali su na visoke vrednosti KIp od 6,1 kod dece uzrasta od 12 godina, odnosno 9,6 kod petnaestogodišnjaka. Poslednjih decenija nisu rađene studije o rasprostranjenosti karijesa na teritoriji Bosne i Hercegovine. Na osnovu studije rađene 1999. godine u Sarajevu [11], prevalencija karijesa kod dece uzrasta 12-15 godina bila je 96,98\% ili, prosječno, 7,18 obolelih zuba po osobi. Ovi rezultati su slični vrednostima dobijenim u našoj studiji. Ivanković i saradnici [12] su 1997. godine na teritoriji kantona zapadne Hercegovine, Herceg-Mostarskog i Posavskog kantona ustanovili karijes kod 94\% dvanaestogodišnjaka, dok je KIp bio 6,2. U istraživanju Obradovića i Dotlića [13] analizirano je stanje zuba banjalučkih dvanaestogodišnjaka; zabeležene su nešto veće vrednosti KIp kod dece iz seoske sredine $(6,74)$ u odnosu na njihove vršnjake koji žive u gradu $(4,89)$. Studija koja je obuhvatila najveću teritoriju Bosne i Hercegovine urađena je 2008. godine [14]. Na uzorku od 560 dvanaestogodišnjaka dobijena je vrednost KIp od 4,16. U svim ovim navedenim istraživanjima komponenta K (karijes) bila je najčešća; slede komponenta $\mathrm{P}$ (plombe) i E (ekstrahovani zubi).

Rajić i saradnici [15] upoređivali su zdravlje zuba kod dece uzrasta od 12 godina koji žive u Hrvatskoj tokom tri decenije. Smanjenje učestalosti karijesa sa 7,0 u 1968. godini na 3,5 u 1999. pripisuje se lokalnoj primeni fluora (u obliku natrijumfluorida i amidnih fluorida) u okviru predškolskog programa prevencije, kao i primeni preventivno-profilaktičkih mera kod trudnica. Kod 227 dece uzrasta 11-14 godina s područja Petrinje i Topuskog ustanovljene su takođe visoke vrednosti KIp $(6,67)$. One su bile veće kod dece koja žive na selu i u manjim naseljima [16]. Studija rađena na teritoriji Crne Gore [17] ukazuje na dosta zadovoljavajuće vrednosti KIp kod dvanaestogodišnjaka u odnosu na vrednosti dobijene našim istraživanjem. KIp je bio 3,43, dok je dece s obolelim stalnim zubima bilo $88,35 \%$. Na teritoriji Srbije Kostadinović i saradnici [18] utvr- dili su da je kod dece uzrasta od 13 godina koja žive u Niškom regionu vrednosti KIp manja $(3,60)$ nego kod njihovih vršnjaka iz Surdulice $(9,18)$. Najnoviji podaci, dobijeni istraživanjem izvedenim 2009. godine na Klinici za dečju i preventivnu stomatologiju Stomatološkog fakulteta u Beogradu za potrebe izrade preventivnog programa Republike Srbije [19, 20], pokazali su da je kod dvanaestogodišnjaka prosečan broj obolelih zuba 2,8, a kod petnaestogodišnjaka 5,6. U Sloveniji je, zahvaljujući dobro organizovanim programima prevencije, a pre svega redovnim četkanjem zuba pastama bogatim fluorom, upotrebom drugih sredstva za ličnu oralnu higijenu i profilaktičkim zalivanjem fisura, tokom perioda 1987-1998. godine došlo do smanjenja rasprostranjenosti karijesa sa 5,1 na 1,8 kod dvanaestogodišnjaka, odnosno sa 10,2 na 4,3 kod petnaestogodišnjaka [4]. Nacionalna studija izvedena 2004. i 2005. godine u Italiji na uzorku dece uzrasta od 12 godina zabeležila je vrednost KIp od 1,09 i razliku između polova koja je bila statistički značajna (1,20 kod devojčica i 0,99 kod dečaka) [21]. Zahvaljujući promeni navika u pogledu održavanja higijene usta i zuba, primeni fluorida u vidu tableta i gelova i pasti bogatih fluorom, u Mađarskoj je u periodu 1985-1996. godine došlo do smanjenja prevalencije karijesa kod dvanaestogodišnjaka sa 5,0 na 3,8 [22]. Uvođenjem programa prevencije, te uključivanjem nastavnika $\mathrm{u}$ lanac prenošenja obaveštenja o važnosti zdravlja, u Poljskoj je od 1995. do 2000. godine smanjena vrednost KIp kod dece uzrasta od 12 godina sa 4,2 na 3,8 [5]. Prema kriterijumima SZO o prevalenciji karijesa za uzrast od 12 godina, do 2020. godine KIp bi trebalo da bude najviše 1,5 [23]. Ovu vrednost dostigle su jedino skandinavske zemlje [24]. U Danskoj je ona 0,8 , u Švedskoj 1,0, u Finskoj 1,2, a u Norveškoj 1,6. Vrednosti KIp kod dvanaestogodišnjaka u Portugalu je 1,5 [25].

Osnova za sticanje pozitivnih stavova o zdravlju uopšte, a samim tim i o oralnom zdravlju, nalazi se u okruženju porodice. Veliki uticaj na pravilno formiranje ličnosti takođe imaju škola i njena vaspitno-obrazovna svrha. Naravno, za očuvanje i unapređenje sopstvenog zdravlja neophodni su saveti i profilaktičko-terapijske intervencije lekara. Dečji stomatolog je osoba koja će, zahvaljujući redovnim kontrolama, prva uočiti promene u usnoj šupljini pacijenta i pravovremeno reagovati. Prema već pomenutim kriterijumima SZO, vrednosti utvrđene u ovoj studiji veoma su visoke $(\mathrm{KIp}=5,64)$ [23].

Karijes je i dalje veliki društveni i zdravstveni problem u većini industrijski razvijenih zemalja, ali i u zemljama u razvoju, koji nastaje usled povećanja potrošnje šećera, neodgovarajuće primene fluorida i ograničenog pristupa uslugama očuvanja oralnog zdravlja. Zbog toga je neophodno promeniti navike $\mathrm{u}$ ishrani i održavanju higijene usta i zuba, te revidirati korišćenje fluorida, bilo preko fluorisane pijaće vode, fluorisanog mleka, soli, pasti za zube bogatih fluorom ili njihove kombinacije.

Za uspešno smanjenje učestalosti karijesa Marthaler (Marthaler) i Petersen (Petersen) [26] i Mejer-Likel (Meyer-Lueckel) i saradnici $[27,28]$ ukazali su na značaj praktičnog aspekta programa fluorisane soli, gde se kao pozitivan primer navode Jamajka i Švajcarska. U Švajcarskoj (Kanton Ciriha) [26] vrednost KIp za dvanaestogodišnjake se sa 8,2 smanjio na 1,1, dok je u nekim regionima Jamajke $[27,28]$ vrednost ovog indeksa kod dvanaestogodišnjaka bila 2,2 (1999. godine), odnosno 2,5 (2006. godine), i 3,8 kod petnaestogodišnjaka. Značaj fluorisane pijaće vode na smanjenje prevalencije karijesa uočili su i Saliba (Saliba) i saradnici [29], a efekte primene različitih 
oblika fluorizacije Pontigo-Lojola (Pontigo-Loyola) i saradnici [30]. Prema savremenim shvatanjima, prednost treba dati lokalnoj primeni fluorida.

Naše istraživanje je pokazalo da su vrednosti KIp visoke i sličnije vrednostima zabeleženim u zemljama severne i zapadne Evrope od pre nekoliko decenija. To se može tumačiti i periodom nestabilnosti socioekonomske egzistencije, koji je ostavio dubok trag na deci koja žive na istraživanim regionima.

\section{ZAKLJUČAK}

Karijes je i dalje jedno od najčešći infektivnih bolesti ovog područja. S obzirom na loše stanje zdravlja zuba dece ovog regiona, neophodno je više pažnje posvetiti organizovanju preventivnih i profilaktičkih mera radi očuvanja i unapređenja oralnog zdravlja stanovništva. Da bi se popravilo postojeće stanje zdravlja učenika, nije dovoljna samo uloga stomatologa, već je neophodna i pomoć države, koja određene propise treba da reguliše i adekvatno ih primenjuje. 